\title{
Analysis of the role of new media in basic party construction and ideological and political education of College Students
}

\author{
Zhu Jinguang ${ }^{1}$, Xu Qiaoxin ${ }^{2}$ \\ ${ }^{1}$ Hankou University, Wuhan, China, 430212 \\ ${ }^{2}$ School of electronic and information engineering, Hankou University, Wuhan 430212, China
}

Keywords: New media, University party construction, Political Education.

\begin{abstract}
With the continuous improvement of people's living standards, education has been made more and more attention. The university has become a place where everyone needs further study, and it is likewise the most concentrated place for the outstanding young people of today. Contemporary college students are the builders of socialism in the future. They must have high political awareness and excellent professional standards. At the same time, we must have reliable comprehensive quality, so as to prepare for the future construction of our motherland. But at the same time, the university student party building work is also facing the impact of new media, highlighting the problems of college students as the main users of the new technology makes the teacher to the work of Party building and ideological and political work on how to strengthen the college students' use of this new form has become the work of higher education faces.
\end{abstract}

\section{The definition of new media}

The new media means several forms of information dissemination to the masses through wireless communication technologies, such as computers, digital television and mobile phones. The main feature of new media is digital, professional and personalized. With the new media relying on computer digital technology, the new media make the new information reception mode no longer limited by space and time, and greatly expand the scope and content of services. Become a popular way, but also the biggest advantage of new media[1].

\section{The ideological and political education of college students in the current problems}

Because of the great advantages of the new media, the students' own life and learning habits are constantly changing, and the traditional ways of obtaining information have also undergone tremendous changes. College Students' information acquisition methods are more diversified and convenient, which makes them more and more inclined to use the computers and mobile phones and other new media terminals to find the problems they need to understand. But in this process, students are vulnerable to the invasion and harassment of foreign dross culture. As the information and content on the Internet are intermingled and intermingled, and the ideological consciousness of college students is not mature enough, it is difficult to resist and resist the influence of decadent ideas in ideology. Thus develop bad habits and attitude to life, the wrong outlook on life and values; ignore shape their own ideology, studies, corrupt social values, increasing the difficulty of the ideological and political education in school[2].

The important role of new media in the party building and ideological and political education of College Students

The ideological and political education of college students is an important guarantee for college students to set up a correct outlook on life and values, as well as the basic requirements for college 
students to be able to stand in society in the future. In the process of traditional ideological and political education in universities, teachers mainly rely on the understanding of textbooks and the understanding and judgment of students. In content more monotonous, not rich enough, has always been a weakness. To some extent, it is this traditional and single way that prevents students from improving their ideological education and their interests. The effect of digestion is reduced and the effect of teaching is reduced. The new media provides inexhaustible and inexhaustible information resources for the ideological and political education of college students with its rich and varied information, the mode of communication beyond time and space, and the mode of instant interaction. The emergence and development of new media can make up this short board, because this new mode of information dissemination transcends the limitations of time and space, and can maximize the human civilization achievements have been extracted. It provides rich information sources and contents for college students. Through the new media, students can understand the focus of current society, the party and the state of the new guidelines and instructions, and can learn from the essence, speed up their outlook on life and values, and promote the formation and development of their own correct ideas of value[3].

In the traditional ideological and political education of college students, the channels of education are mainly concentrated in classroom teaching, occasionally accompanied by individual conversation, collective discussion and other traditional ways. However, this traditional way of learning is limited by time and limited by space, which makes the original educational channel relatively narrow. But these in the development of new media has become the moment is no longer a problem, between educators and students can through the new way of communication to spread a large amount of information, by e-mail, WeChat or Baidu cloud network platform, teachers and students can make a deep interaction and communication, all-weather, non neutral communicate with. This has greatly expanded the scope of Ideological and political education of college students, and enriched the means and methods of education. It is beneficial for educators to use various new media platforms to observe and pay attention to the students' thinking trends, so as to know the students' psychological and emotional needs in a timely manner. The education in the new media era is faster, more convenient, and improves the efficiency of education.

In the traditional ideological and political education, teacher education form and means of rigid forms of didactic serious, can not meet the new needs of college students caused by the decay of the quality of education, so that the expected goals of education can not be reached. But the use of new media will avoid these problems, and new media can use various forms to produce sensory stimulation on the human body. And can set up a diversified system of thinking and emotion output. For example, the new media can use video, music, animation and other pain education means can not be used in a deep and intuitive teaching experience. This "trendy" approach to education is more easily accepted by college students and is more easily accepted by young people. Greatly improve the efficiency of students learning and teaching efficiency of teachers. As a result, teachers can help students constantly build their own outlook on life and values, and help college students to grow and work better in their future life journey[4].

\section{Under the new media environment, how to strengthen the party building and ideological and political education of college students?}

With the development of information age, type of source of information and information has become diverse, which requires the ideological and political work related personnel should improve the ability to identify information, establish the correct orientation of Ideological and political education of College Students under the new media. By combining the actual situation with the virtual situation, we analyze and sum up experience to ensure that the new media can transmit positive energy. As educators of Ideological and political education, to improve the response mechanism, adhere to the patriotism as the core, the new media dissemination effect and the guiding ideology of Marxism Leninism, socialist theory Chinese combination. The socialist core values play a guiding role, ensure the same direction of development and construction, and the use of new media to spread fast and wide range of characteristics influence, ensure the ideological and 
political education is the right direction, and continuous efforts. Only if we set the right direction, all efforts will be effective, ideological and political work can continue, and more conducive to students in the future growth and development.

The workers of Ideological and political education in Colleges and universities should first understand the ability to adapt to the new media and have the ability to use new media scientifically. This kind of curriculum arrangement in University, mainly in order to let the students establish a correct outlook on life, values, the ability to have certain ideological consciousness and right from wrong. The ideological and political education can not be separated from the communication between educators and college students. At this time, we should use the new media to carry out good emotional communication. Educators should keep pace with the times, spend more time in contact with new media, the use of new media to learn knowledge, understand the trends of social development, but also can better grasp the change of students' thought, in order to understand the change of students' overall found the problem, use the network language to the students spread positive energy, help students rational view of social problems. The use of new media to enhance students' Ideological and political ability, which means that educators should first learn, use new media, integrate into it, spread positive energy. In practice, to improve their ability to control the new media, and thus make full use of the new media for ideological and political education of college students important role[5].

The ideological and political education of college students should choose the appropriate method, and the use of new media just focuses on the areas that modern college students are interested in. These students also often open their hearts in the Internet environment and express their true ideas. In this environment, the related educators will develop ideological and political education with the help of new media, which will lead to more effective and more rational thinking. In the campus websites, multi platform sends a positive message, seize the students' interest, in the form of expression of the novel, attracting the attention of the students, influence and help students to establish a correct outlook on life and values, send content should be close to the student life, students understand the concept of single difficult to add more relevant the case, let the students truly understand its connotation. Second, WeChat, QQ and other social networking software is also given the workers and students communicate with the most simple way, regular communication, increase the ideological and political education work carried out in an orderly manner, to stimulate students' enthusiasm for learning, to closely monitor the students' learning and life and emotional problems, timely, ensure the physical and mental health of College students.

As educators, we should set an example, to understand its essence of Ideological and political education, and actively reflected in daily life, only constantly improve their ideological and political ideas, can let the student convince. The traditional method of Ideological and political education can not adapt to the current education, out of touch with the information age, out of touch with the new media, can not meet the development of College Students' ideological education, which requires educators to carefully study the development, combined with the characteristics of the new media era, continuous improvement and improvement. As educators, we should enhance their comprehensive ability, pay more attention to the affairs of state, pay attention to social hot topics, know when and national development and growth, with the party to restrain their behavior in time, timely self reflection, to find problems, analyze problems, to solve the problem, the important thought of the new media propaganda of the party, transfer more positive energy for college students, in the field of ideology education, but also to our party's ideological content is the important premise, spread to the students the correct ideas, to urge the students to learn the important articles of association, gang party collar, theory, route, time constraints themselves, understand their compliance with the requirements of the doings of party this can improve work efficiency, the ideological and political education. Effectively enhance the party members, teachers, ideological and political education workers own ability, teaching can be more scientific and efficient, in real sense, have a positive impact on College Students' Ideological concepts[6].

Members of the university are in the study and life of positive thinking. The backbone of the work, has a certain representation. To make the ideological and political work smoothly and 
efficiently carry out, let the student party members play an exemplary role, the advantage of the new media, to guide the party members of college students strict demands on themselves, actively promote new ideas, the party's lead, establish a good image, at the same time, College students, contact time in life more and more effective communication effect. This is because the power of example is infinite, especially in addition, as the ideological and political education of the staff, to remind students to the new media technology development situation, strengthen their ideals and beliefs, closely follow the pace of the party, in the daily handling of the issue, to comply with the provisions of the party. Under the new media environment, the freedom of speech, will affect their ideas to a certain extent, student party members to stand firm, avoid disorientation, to learn how to use the advantages of the new media, enhance the ability to distinguish right from wrong, positive propaganda of the party, to become qualified builders of socialism.

With the deepening of China's reform process, the employment problem of college students has encountered great obstacles. Many factors have a bearing on College Students' career choice. Therefore, the education of College Students' employment is also the key link of Party building and political education. The ideological and political education is indispensable for college students in their employment choices, which are directly related to the steady development of society. In the thought and politics education in the University, students should pay attention to the correct ideas, stimulate the patriotic enthusiasm of the students, teach students how to properly handle the national and personal interests, cultivate students' sense of responsibility and the spirit of collectivism. The development of information technology, network world, freedom of speech, bad temptation under the new media era is increasing, it is particularly important to cultivate students' ability to distinguish between right and wrong, educators should often students to spread positive energy, to ensure that students with mental health, positive spirit, so that students can live in healthy environment, influence to reduce the adverse factors on students. "Xing Xing is the national youth, youth country", as we work to education, the key link in the college graduates employment of students, students to spread positive energy, to guide the students to keep the patriotic enthusiasm, actively participate in the implementation of China dream work, become qualified successors of socialism.

Modern society, science continues to develop, the new media also changes with each passing day, and the Students' Party building and ideological and political education need to be strengthened. In order to realize the great dream of China, attention should be paid to the new generation of Youth Ideological and political education of universities, education workers should in accordance with the actual situation under the premise of education, using scientific and reasonable methods, training students to the maximum, the correct theory faith, brave, dare to innovate, have the sense of social responsibility, assume responsibility for the construction of the motherland, to achieve the great rejuvenation of the China dream, my contribution.

\section{References}

[1]Zhang K B A, Kun-peng b X U. On the Basic Law That Must Be Grasped and Followed in College Students' Ideological and Political Education[J]. Journal of Shenyang Agricultural University, 2010.

[2]Guan Q W. Practice Research on College Students' Ideological and Political Education in the Context of New Media[J]. Education Teaching Forum, 2017.

[3]Liu X H. Feasibility Analysis of Integrating Party Construction and Ideological-political Education in New Era University Students[J]. Journal of China Three Gorges University, 2006.

[4]Lin L P. The role of new media in the party building and ideological and political education in colleges and universities[J]. Journal of Jiamusi Vocational Institute, 2016.

[5]Qing-Ming F U. Reflections on ideological and politicaleducation of college students in the new century[J]. Journal of Liaoning Technical University, 2004. 
[6]Gao W, Zhang Z, University S S. Ideological and Political Education's Construction of Long-term Mechanism about College Student Party Members under the Guidance of Socialist Core Values[J]. Guide of Science \& Education, 2015. 